\title{
Pemodelan Persentase Penduduk Miskin di Provinsi Kalimantan Timur Menggunakan Model Geographically Weighted Panel Regression
}

Arjun Pratama

Universitas Mulawarman, arjunpratama2412@gmail.com

Suyitno

Universitas Mulawarman, suyitno272808@gmail.com

\section{Ika Purnamasari}

Universitas Mulawarman, ikapurnamasari212@gmail.com

ABSTRAK. Model Geographically Weighted Panel Regression (GWPR) merupakan pengembangan model regresi panel yang diaplikasikan pada data spasial. Model GWPR yang dibahas pada penelitian ini adalah Fixed Effect Model (FEM) spasial. Penaksiran parameter model GWPR dilakukan pada setiap lokasi pengamatan menggunakan pembobot spasial. Tujuan penelitian ini adalah mengetahui faktor-faktor yang mempengaruhi persentase penduduk miskin tahun 2017-2019 di 10 Kabupaten/Kota Provinsi Kalimantan Timur. Penaksiran parameter model GWPR menggunakan metode Weighted Least Square (WLS). Pembobot spasial pada penaksiran parameter ditentukan menggunakan fungsi pembobot terbaik di antara pembobot fixed gaussian, fixed bisquare, fixed tricube, dan adaptive bisquare. Penentuan bandwidth optimum menggunakan kriteria Cross Validation (CV) dan diperoleh fungsi pembobot dengan nilai CV minimum adalah adaptive bisquare. Berdasarkan hasil pengujian parameter model GWPR, disimpulkan bahwa faktor-faktor yang berpengaruh terhadap persentase penduduk miskin bersifat lokal dan berbedabeda di 10 kabupaten/kota di Provinsi Kalimantan Timur. Faktor-faktor yang berpengaruh dan bersifat local terhadap persentase penduduk miskin adalah indeks pembangunan manusia, umur harapan hidup, pendapatan domestik regional bruto, tingkat partisipasi angkatan kerja, tingkat pengangguran terbuka, dan laju pertumbuhan penduduk. Berdasarkan nilai koefisien determinasi dan Root Mean Square Error (RMSE) diperoleh bahwa model GWPR lebih baik daripada model regresi panel global dengan nilai koefisien determinasi sebesar 94,40\% dan nilai RMSE sebesar 0,0451.

Kata Kunci: $\quad G W P R$, Koefisien Determinasi, Persentase Penduduk Miskin, Provinsi Kalimantan Timur, RMSE

\section{PENDAHULUAN}

Kemiskinan adalah ketidakmampuan dari sisi ekonomi untuk memenuhi kebutuhan dasar makanan dan bukan makanan yang diukur dari sisi pengeluaran. Penduduk miskin adalah penduduk yang memiliki rata-rata pengeluaran perkapita perbulan dibawah garis kemiskinan[1] Faktor-faktor penyebab kemiskinan dapat berupa karakteristik rumah tangga dan individu.
Beberapa karakteristik rumah tangga dan individu yang mempengaruhi kemiskinan dikelompokkan menjadi tiga, yaitu karakteristik demografi, ekonomi, dan sosial[2]. Tingkat kemiskinan dipengaruhi oleh faktor spasial, misalnya sumber daya alam, akses untuk layanan kesehatan dan pendidikan di daerah tersebut[3].

Data persentase penduduk miskin memiliki pengaruh yang berbeda di setiap daerah sehingga dianggap sebagai data panel spasial. Data panel spasial tidak tepat jika dimodelkan menggunakan regresi panel, karena terdapat asumsi yang terlanggar yaitu asumsi homoskedastisitas[4]. Alternatif yang dapat digunakan untuk memodelkan data panel spasial yaitu model GWPR. Model GWPR pada penelitan ini dibatasi pada model GWPR FEM. Pertimbangan model FEM digunakan, karena tidak memuat intersep, sehingga tidak memerlukan penaksiran konstanta pada model GWPR[5]. Metode GWPR memiliki kelebihan dalam memberikan hasil penaksir yang baik, karena mempertimbangkan aspek lokasi dan waktu serta gabungan dari analisis regresi panel dan GWR[4].

Salah satu Provinsi di Indonesia yang mengalami peningkatan persentase penduduk miskin adalah Provinsi Kalimantan Timur sebesar $0,45 \%$ dari tahun 2017-2020[6]. Data persentase penduduk miskin di Provinsi Kalimantan Timur dapat dimodelkan menggunakan model GWPR karena merupakan data panel spasial yang mengandung unsur lokasi dan waktu yang berbeda.

\section{TINJAUAN PUSTAKA}

\section{Model Regresi Panel}

Data Panel merupakan data gabungan dari cross section dan time series yang berarti data 
panel adalah data yang dikumpulkan pada waktu yang berbeda dan unit pengamatan yang berbeda. Terdapat tiga model regresi panel yakni Common Effect Model (CEM), Random Effect Model (REM), dan Fixed Effect Model (FEM).

Bentuk umum model FEM adalah sebagai berikut[7]:

$$
\begin{aligned}
& y_{i t}=\beta_{F_{0 i}}+x_{i t 1} \beta_{F_{1}}+x_{i t 2} \beta_{F_{2}}+\ldots+x_{i t p} \beta_{F_{p}}+\varepsilon_{i t} \\
& i=1,2, \ldots, n ; t=1,2, \ldots, T
\end{aligned}
$$

$\beta_{F_{0 i}}$ pada persamaan (2.1) menunjukkan bahwa intersep dari tiap unit cross-section adalah berbeda. Penaksiran parameter FEM dilakukan dengan mentransformasi $\beta_{F_{0 i}}$ melalui metode within estimator[5]. Within estimator menggunakan data demean yang dibentuk dengan mengurangkan data aktual terhadap ratarata time series[8]. Diperoleh persamaan within estimator sebagai berikut:

$$
\bar{y}_{i}=\beta_{F_{0 i}}+\bar{x}_{i 1} \beta_{F_{1}}+\bar{x}_{i 2} \beta_{F_{2}}+\ldots+\bar{x}_{i p} \beta_{F_{p}}+\bar{\varepsilon}_{i}
$$

dimana,

$$
\bar{y}_{i}=\frac{1}{T} \sum_{t=1}^{T} y_{i t}, \bar{x}_{i k}=\frac{1}{T} \sum_{t=1}^{T} x_{i t k}, \bar{\varepsilon}_{i}=\frac{1}{T} \sum_{t=1}^{T} \varepsilon_{i t}
$$

Model FEM within estimator diperoleh dengan mengurangkan persamaan (2.1) dan persamaan (2.2), sehingga menjadi

$$
\begin{aligned}
\left(y_{i t}-\bar{y}_{i}\right)= & \left(\beta_{F_{0 i}}-\beta_{F_{0 i}}\right)+\left(x_{i t 1}-\bar{x}_{i 1}\right) \beta_{F_{1}}+ \\
& \left(x_{i t 2}-\bar{x}_{i 2}\right) \beta_{F_{2}}+\ldots+\left(x_{i t p}-\bar{x}_{i p}\right) \beta_{F_{p}} \\
& +\left(\varepsilon_{i t}-\bar{\varepsilon}_{i}\right) ; i=1,2, \ldots, n ; t=1,2, \ldots T
\end{aligned}
$$

persamaan (2.4) dapat disederhanakan menjadi:

$$
\begin{aligned}
& y_{i t}^{*}=x_{i t 1}^{*} \beta_{F_{1}}+x_{i t 2}^{*} \beta_{F_{2}}+\ldots+x_{i t p}^{*} \beta_{F_{p}}+\varepsilon_{i t}^{*} \\
& ; i=1,2, \ldots, n ; t=1,2, \ldots, T
\end{aligned}
$$

persamaan (2.5) dapat dituliskan dalam bentuk matriks menjadi

$$
\mathbf{y}^{*}=\mathbf{X}^{*} \boldsymbol{\beta}_{F}^{T}+\boldsymbol{\varepsilon}^{*}
$$

dengan $\mathbf{y}^{*}=\left(y_{i t}-\bar{y}_{i}\right) ; \mathbf{X}^{* T}=\left(x_{i t k}-\bar{x}_{i k}\right)$.

Parameter $\boldsymbol{\beta}_{F}$ ditaksir menggunakan Ordinary Least Square (OLS) sehingga diperoleh[9],

$$
\hat{\boldsymbol{\beta}}_{F}=\left(\mathbf{X}^{* T} \mathbf{X}^{*}\right)^{-1} \mathbf{X}^{* T} \mathbf{y}^{*} \text {. }
$$

\section{Pengujian Hipotesis Model Regresi Panel}

Pengujian parameter model regresi panel dilakukan dengan pengujian secara simultan dan parsial. Uji simultan digunakan untuk mengevaluasi variabel bebas secara simultan terhadap variabel terikat dengan hipotesis adalah[10]:

$\mathrm{H}_{0}: \beta_{F_{1}}=\beta_{F_{2}}=\ldots=\beta_{F_{p}}=0$

$\mathrm{H}_{1}$ : minimal ada satu $\beta_{F_{k}} \neq 0, k=1,2, \ldots, p$

Statistik uji adalah sebagai berikut:

$$
F_{1}=\frac{K T R}{K T G}
$$

$K T R$ adalah kuadrat tengah regresi dan $K T G$ adalah kuadrat tengah galat. Statistik uji $F_{1}$ berdistibusi $F_{(p ; n T-n-p)}$. Daerah kritis adalah menolak $\mathrm{H}_{0}$ pada taraf signifikansi $(\alpha)$ jika $F_{1}>F_{(\alpha ; p ; n T-n-p)}$ atau menolak $\mathrm{H}_{0}$ jika pvalue ${ }_{1}<\alpha$

Uji parsial digunakan untuk membuktikan apakah variabel bebas secara individu mempengaruhi variabel terikat. Hipotesis uji parsial adalah[11]:

$\mathrm{H}_{0}: \beta_{F_{k}}=0$

$\mathrm{H}_{1}: \beta_{F_{k}} \neq 0$

Statistik uji yang digunakan adalah :

$$
T_{1}=\frac{\hat{\beta}_{F_{k}}}{s \sqrt{g_{k k}}}
$$

dengan $s=J K G /(n T-p), g_{k k}=\operatorname{diag}\left[g_{11} g_{22} \ldots g_{p p}\right]$ dan $\mathrm{g}_{k k}$ adalah elemen matriks $\left(\mathbf{X}_{F}^{* T} \mathbf{X}_{F}^{*}\right)^{-1}$.

Daerah kritis adalah menolak $\mathrm{H}_{0}$ pada taraf signifikansi $(\alpha)$ adalah jika $\left|T_{1}\right| \geq t_{(\alpha / 2, n T-p)}$ atau menolak $\mathrm{H}_{0}$ jika pvalue ${ }_{2}<\alpha$.

\section{Pendeteksian Multikolinearitas}

Metode yang digunakan dalam mendeteksi adanya multikolinearitas adalah dengan melihat nilai Variance Inflation Factor (VIF). Multikolinearitas terjadi apabila nilai VIF lebih besar dari 10[12].

$$
V I F_{k}=\frac{1}{1-R_{k}^{2}}
$$

$R_{k}^{2}$ adalah koefisien determinasi saat $\mathrm{X}_{\mathrm{k}}$ diregresikan dengan variabel bebas lainnya. 


\section{Asumsi Model Regresi Linier Berganda}

\section{a. Asumsi Homoskedastisitas}

Homoskedastisitas terjadi akibat adanya perbedaan karakteristik satu wilayah dengan wilayah lainnya. Pengujian dilakukan dengan menggunakan uji Glejser. Hipotesis pengujian adalah[13]:

$\mathrm{H}_{0}: \sigma_{1}^{2}=\sigma_{2}^{2}=\ldots=\sigma_{n}^{2}=\sigma^{2}$

$\mathrm{H}_{1}$ : minimal ada satu $\sigma_{i}^{2}=\sigma^{2} ; i=1,2, \ldots, n$

Statistik uji Glejser diberikan oleh

$$
F_{2}=\frac{\left(\hat{\boldsymbol{\varphi}}^{T} \mathbf{X}^{T} \boldsymbol{\varepsilon}-n \bar{\varepsilon}^{2}\right) / p}{\left(\boldsymbol{\varepsilon}^{T} \boldsymbol{\varepsilon}-\hat{\boldsymbol{\varphi}}^{T} \mathbf{X}^{T} \boldsymbol{\varepsilon}\right) /(n-p-1)}
$$

Statistik uji $F_{2}$ mengikuti distribusi $F_{(p ; n-p-1)}$. Daerah kritis adalah menolak $\mathrm{H}_{0}$ jika $F_{2}>F_{\alpha ; p ;(n-p-1)}$ atau menolak $\mathrm{H}_{0}$ jika pvalue $3<\alpha$.

\section{b. Asumsi Non-Otokorelasi}

Otokorelasi dalam konsep regresi linier berarti komponen galat berkorelasi berdasarkan urutan waktu atau urutan ruang[10]. Pengujian menggunakan uji Durbin-Watson dengan hipotesis adalah[14]:

$$
\begin{aligned}
& \mathrm{H}_{0}: \rho=0 \\
& \mathrm{H}_{1}: \rho \neq 0
\end{aligned}
$$

Statistik uji Durbin-Watson adalah

$$
D W=\frac{\sum_{i=2}^{n}\left(\varepsilon_{i}-\varepsilon_{i-1}\right)^{2}}{\sum_{i=2}^{n} \varepsilon_{i}^{2}},
$$

\begin{tabular}{|c|c|c|}
\hline No & Kriteria & Keputusan \\
\hline 1 & Jika $0<D W<d L$ & $\begin{array}{l}\text { otokokorelasi } \\
\text { positif }\end{array}$ \\
\hline 2 & Jika $4-d L<D W<4$ & $\begin{array}{l}\text { otokokorelasi } \\
\text { negatif }\end{array}$ \\
\hline 3 & $\begin{array}{l}\text { Jika } 2<D W<4-d U \\
\text { atau } d U<D W<2\end{array}$ & $\begin{array}{l}\text { tidak ada } \\
\text { otokorelasi }\end{array}$ \\
\hline 4 & $\begin{array}{l}\text { Jika } d L \leq D W \leq d U \text { atau } \\
4-d U<D W<4-d L\end{array}$ & $\begin{array}{l}\text { pengujian tidak } \\
\text { meyakinkan. }\end{array}$ \\
\hline
\end{tabular}

Kriteria pengujiannya disajikan pada Tabel 2.1 sebagai berikut :

Tabel 2.1 Kriteria Pengujian Dubin-Watson

\section{c. Asumsi Normalitas Galat}

Asumsi kenormalan menghasilkan penaksir OLS yang mempunyai sifat tidak bias, efisien, dan konsisten[15]. Salah satu metode pengujian hipotesis normalitas adalah dengan uji JarqueBera (JB). Hipotesis uji JB adalah sebagai berikut[16]:

$\mathrm{H}_{0}: \mu_{i}=0$

$\mathrm{H}_{1}: \mu_{i} \neq 0$

Statistik uji adalah JB yaitu

$$
J B=n\left[\frac{S^{2}}{6}+\frac{(K-3)^{2}}{24}\right]
$$

dimana

$$
S=\frac{\sum_{i=1}^{n}\left(\varepsilon_{i}-\bar{\varepsilon}\right)^{3}}{n s^{3}} \quad ; K=\frac{\sum_{i=1}^{n}\left(\varepsilon_{i}-\bar{\varepsilon}\right)^{4}}{n s^{4}}
$$

Statistik uji JB mengikuti distribusi $\chi_{2}^{2}$. Daerah kritis adalah menolak $\mathrm{H}_{0}$ pada taraf signifikansi $(\alpha)$ jika $J B \geq \chi_{(\alpha, 2)}^{2}$ atau menolak $\mathrm{H}_{0}$ jika pvalue $_{4}<\alpha$.

\section{Pembobot Spasial pada Model Geographically Weighted Regression}

Beberapa literatur yang bisa digunakan untuk menentukan besarnya pembobot untuk tiap lokasi yang berbeda pada model GWR, diantaranya dengan menggunakan fungsi kernel atau kernel function [17].

Pembobot yang terbentuk dengan fungsi kernel ini dapat dibedakan menjadi :

1. Fungsi Kernel Fixed, yaitu fungsi kernel yang memiliki bandwidth yang sama pada setiap lokasi pengamatan. Fungsi kernel ini diantaranya adalah

(i) Fixed Gaussian

$$
w_{i j}=\exp \left(-\frac{1}{2}\left(\frac{d_{i j}}{h}\right)^{2}\right)
$$

(ii) Fixed Bisquare

$$
w_{i j}=\left\{\begin{array}{l}
\left(1-\left(\frac{d_{i j}}{h}\right)^{2}\right)^{2}, \text { jika } d_{i j} \leq h \\
0, \text { untuk } d_{i j} \text { yang lain }
\end{array}\right.
$$

(iii) Fixed Tricube 


$$
w_{i j}=\left\{\begin{array}{c}
\left(1-\left(\frac{d_{i j}}{h}\right)^{3}\right)^{3}, \text { jika } d_{i j} \leq h \\
0, \text { untuk } d_{i j} \text { yang lain }
\end{array}\right.
$$

$d_{i j}$ adalah jarak antara titik di lokasi $i$ dan lokasi $j$ yang didapatkan dari jarak euclidean $\left(d_{i j}\right)^{2}=\left(u_{i}-u_{j}\right)^{2}+\left(v_{i}-v_{j}\right)^{2}$. Sementara $h$ adalah bandwidth.

2. Fungsi Kernel Adaptive, yaitu fungsi kernel yang memiliki bandwidth yang berbeda-beda pada masing-masing lokasi pengamatan. Salah satu fungsi kernel adaptive adalah fungsi Adaptive Bisquare[18].

$$
w_{i j}=\left\{\begin{array}{l}
\left(1-\left(d_{i j}\right)^{2}\right)^{2}, \text { jika } d_{i j} \leq h \\
0, \text { untuk } d_{i j} \text { yang lain }
\end{array}\right.
$$

dimana $h_{i}$ merupakan bandwidth lokasi pengamatan ke- $i$.

Salah satu metode untuk mendapatkan bandwidth optimum adalah menggunakan Cross Validation (CV). Bandwidth yang optimum diperoleh jika nilai CV yang dihasilkan adalah paling minimum.

$$
C V=\sum_{i=1}^{n}\left[y_{i}-\hat{y}_{\neq i}(h)\right]^{2}
$$

$\hat{y}_{\neq i}(h)$ adalah nilai taksiran $y_{i}$ dengan menghilangkan pengamatan titik ke- $i$ dari proses pengujian. Proses untuk mendapatkan bandwidth yang meminimumkan nilai CV dilakukan menggunakan Golden Section Search[18].

\section{Model Geographically Weighted Panel Regression}

Metode GWPR merupakan model regresi lokal dengan pengulangan data pada titik lokasi untuk setiap pengamatan pada waktu yang berbeda[19]. Berikut adalah kombinasi dari persamaan GWR dan regresi panel FEM dengan within estimator pada pengamatan ke- $i$ dan waktu ke- $t$.

$$
\begin{aligned}
y_{i t}^{*}= & \beta_{0}\left(u_{i}, v_{i}\right)+\beta_{1}\left(u_{i}, v_{i}\right) x_{i t 1}^{*}+\beta_{2}\left(u_{i}, v_{i}\right) x_{i t 2}^{*}+ \\
& \ldots+\beta_{p}\left(u_{i}, v_{i}\right) x_{i t p}^{*}+\varepsilon_{i t}^{*}
\end{aligned}
$$

$y_{i t}^{*}$ adalah variabel terikat pada lokasi ke- $i$ dan waktu ke- $t, x_{i t k}^{*}$ adalah variabel bebas ke- $k$ pada lokasi ke- $i$ dan waktu ke- $t, \beta_{0}$ adalah konstanta regresi model GWPR pada lokasi ke- $i$ dan waktu ke- $t, \beta_{k}$ adalah koefisien regresi model GWPR pada variabel bebas ke- $k$ pada lokasi ke- $i$ dan waktu ke- $t,\left(u_{i}, v_{i}\right)$ adalah titik koordinat lokasi ke- $i, \quad \varepsilon_{i t}^{*}$ adalah galat yang diasumsikan independen, identik dan mengikuti distribusi normal dengan mean nol dan varian konstan.

Persamaan (19) dapat dituliskan dalam bentuk matriks menjadi

$$
\mathbf{y}^{*}=\mathbf{X}^{*} \boldsymbol{\beta}\left(u_{i}, v_{i}\right)+\boldsymbol{\varepsilon}^{*} .
$$

Parameter yang dihasilkan pada model GWPR akan berbeda-beda pada masing-masing lokasi, sehingga terdapat $n \times(p+1)$ parameter yang ditaksir, dimana $n$ adalah jumlah lokasi dan $(p+1)$ jumlah parameter pada masing-masing lokasi.

Penaksiran parameter model GWPR dapat menggunakan Weighted Least Square (WLS), dengan memberikan unsur pembobot yang berbeda untuk setiap lokasi dan diperoleh[3],

$$
\hat{\boldsymbol{\beta}}\left(u_{i}, v_{i}\right)=\left(\mathbf{X}^{* T} \mathbf{W}\left(u_{i}, v_{i}\right) \mathbf{X}^{*}\right)^{-1} \mathbf{X}^{* T} \mathbf{W}\left(u_{i}, v_{i}\right) \mathbf{y}^{*}(2.21)
$$
dengan

$\boldsymbol{\beta}\left(u_{i}, v_{i}\right)=\left[\beta_{0}\left(u_{i}, v_{i}\right) \beta_{1}\left(u_{i}, v_{i}\right) \ldots \beta_{p}\left(u_{i}, v_{i}\right)\right]^{T}$

$\mathbf{W}\left(u_{i}, v_{i}\right)=\operatorname{diag}\left(\begin{array}{l}w_{i 11}, w_{i 21}, \ldots, w_{i n 1}, \ldots, \\ w_{i 1 T}, w_{i 2 T}, \ldots, w_{i n T}\end{array}\right)$

\section{Pengujian Hipotesis Model Geographically Weighted Panel Regression}

Pengujian kesesuaian model dilakukan dengan menguji kesesuaian dari parameter secara Simultan. Hipotesis pengujian kesesuaian model adalah sebagai berikut[9]:

$\mathrm{H}_{0}: \beta_{k}\left(u_{i}, v_{i}\right)=\beta_{F_{k}}$

(tidak terdapat perbedaan yang signifikan antara model regresi panel dan GWPR)

$\mathrm{H}_{1}$ : minimal ada satu $\beta_{k}\left(u_{i}, v_{i}\right) \neq \beta_{F_{k}}$

(terdapat perbedaan yang signifikan antara model regresi panel dan GWPR)

Statistik uji adalah uji $F$ sebagai berikut

$$
F_{3}=\frac{J K G\left(\mathrm{H}_{0}\right) / d b_{1}}{J K G\left(\mathrm{H}_{1}\right) / d b_{2}}
$$

dengan 


$$
\begin{aligned}
& J K G\left(\mathrm{H}_{0}\right)=\mathbf{y}^{* T}\left(\mathbf{I}-\mathbf{H}^{*}\right) \mathbf{y}^{*} ; \mathbf{H}^{*}=\mathbf{X}^{*}\left(\mathbf{X}^{* T} \mathbf{X}^{*}\right)^{-1} \mathbf{X}^{* T} \\
& J K G\left(\mathrm{H}_{1}\right)=\mathbf{y}^{* T}\left(\mathbf{I}-\mathbf{L}^{*}\right)^{T}\left(\mathbf{I}-\mathbf{L}^{*}\right) \mathbf{y}^{*} ; d b_{1}=(n T-p-1) \\
& d b_{2}=\delta_{1}^{2} / \delta_{2} ; \delta_{i}=\operatorname{tr}\left(\left(\mathbf{I}-\mathbf{L}^{*}\right)^{T}\left(\mathbf{I}-\mathbf{L}^{*}\right)\right)^{i}, i=1,2,
\end{aligned}
$$

I merupakan matriks identitas berukuran $n T \times n T$ dan $\mathbf{L}$ merupakan matriks proyeksi dari model GWPR. $F_{3}$ mengikuti distribusi $F_{\mathrm{db} 1 ; \mathrm{db} 2}$. Daerah kritis adalah menolak $\mathrm{H}_{0}$ pada taraf signifikansi $(\alpha)$ jika $F_{3}>F_{\alpha, d b_{1}, d b_{2}}$ dimana $d b_{1}=(n T-p-1)$ dan $d b_{2}=\delta_{1}^{2} / \delta_{2}$ atau menolak $\mathrm{H}_{0}$ jika pvalue $e_{5}<\alpha$

Pengujian parameter parsial model GWPR untuk mengetahui variabel bebas $X_{k}$ yang berpengaruh pada lokasi ke- $i$ dengan hipotesis adalah[8]:

$$
\begin{aligned}
& \mathrm{H}_{0}: \beta_{k}\left(u_{i}, v_{i}\right)=0 \\
& \mathrm{H}_{1}: \beta_{k}\left(u_{i}, v_{i}\right) \neq 0
\end{aligned}
$$

Statistik uji adalah uji $T_{2}$ sebagai berikut

$$
T_{2}=\frac{\hat{\beta}_{k}\left(u_{i}, v_{i}\right)}{\hat{\sigma} \sqrt{c_{k k}}}
$$

$c_{k k}$ adalah elemen diagonal ke- $k$ dari matriks $\mathbf{C}_{i} \mathbf{C}_{i}^{T} \quad$ dimana $\quad \mathbf{C}_{i}=\left(\mathbf{X}^{* T} \mathbf{W}\left(u_{i}, v_{i}\right) \mathbf{X}^{*}\right)^{-1} \mathbf{X}^{* T} \mathbf{W}\left(u_{i}, v_{i}\right)$, $\hat{\sigma}=J K G\left(\mathrm{H}_{1}\right) / \delta_{1} . \mathrm{T}_{2}$ akan mengikuti distribusi $t$ dengan derajat bebas $\delta_{1}^{2} / \delta_{2}$. Daerah kritis adalah menolak $\mathrm{H}_{0}$ pada taraf signifikansi $(\alpha)$ jika $\left|T_{2}\right|>t_{\alpha / 2 ; \delta_{1}^{2} / \delta_{2}}$ atau menolak $\mathrm{H}_{0}$ jika pvalue $_{6}<\alpha$.

\section{Ukuran Kebaikan Model Regresi Panel dan Model Geographically Weighted Panel Regression}

\section{a. Koefisien Determinasi}

Koefisien determinasi $\left(R^{2}\right)$ adalah ukuran kebaikan model yang menunjukkan seberapa kuat variabel bebas berpengaruh kepada variabel terikat, semakin tinggi nilai $R^{2}$ maka model semakin baik[16]. Bentuk umum $R^{2}$ diberikan sebagai berikut:

$$
R^{2}=\frac{J K R}{J K T}
$$

dimana JKR adalah jumlah kuadrat regresi dan JKT adalah jumlah kuadrat total. Nilai koefisien determinasi terletak di antara 0 dan 1[16].

\section{b. Root Mean Square Error (RMSE)}

Ukuran kebaikan model regresi panel global maupun GWPR yang akan digunakan adalah Root Mean Square Error (RMSE). Berikut adalah rumus yang digunakan untuk menghitung nilai RMSE[20]:

$$
R M S E=\sqrt{\frac{1}{n} \sum_{i=1}^{n}\left(y_{i}-\hat{y}_{i}\right)^{2}}
$$

\section{Kemiskinan}

Badan Pusat Statistik (BPS) menggunakan konsep kemampuan memenuhi kebutuhan dasar (basic needs approach) dalam mengukur kemiskinan. Kemiskinan dipandang sebagai ketidakmampuan dari sisi ekonomi untuk memenuhi kebutuhan dasar makanan dan bukan makanan yang diukur dari sisi pengeluaran. Jadi, penduduk miskin adalah penduduk yang memiliki rata-rata pengeluaran perkapita perbulan dibawah garis kemiskinan[1].

Faktor-faktor penyebab kemiskinan, pada faktor demogafi diwakili oleh laju pertumbuhan penduduk, tingkat pengangguran terbuka, dan tingkat partisipasi angkatan kerja. Pada faktor ekonomi diwakili oleh pendapatan domestik regional bruto. Pada faktor sosial diwakili oleh umur harapan hidup dan indeks pembangunan manusia.

\section{METODOLOGI PENELITIAN}

\section{Sumber Data dan Variabel Penelitian}

Data penelitian adalah data sekunder yang diperoleh dari BPS Provinsi Kalimantan Timur. Variabel penelitian terdiri dari variabel terikat dan variabel bebas yang terdiri dari tahun 2017 2019 yang disajikan pada Tabel 3.1

Tabel 3.1 Variabel Penelitian

\begin{tabular}{cll}
\hline Variabel & Definisi \\
\hline $\mathrm{Y}$ & Persentase Penduduk Miskin \\
$\mathrm{X}_{1}$ & Indeks Pembangunan Manusia \\
$\mathrm{X}_{2}$ & Umur Harapan Hidup \\
$\mathrm{X}_{3}$ & Pendapatan Domestik Regional \\
& Bruto & \\
$\mathrm{X}_{4}$ & Tingkat Partisipasi Angkatan \\
& Kerja \\
$\mathrm{X}_{5}$ & Tingkat Pengangguran Terbuka \\
$\mathrm{X}_{6}$ & Laju Pertumbuhan Penduduk \\
\hline
\end{tabular}


serta data koordinat lokasi adalah pasangan garis lintang dan bujur dari 10 Kabupaten/Kota di Provinsi Kalimantan Timur.

\section{Tahapan Analisis Data}

Metode analisis yang digunakan dalam penelitian ini adalah GWPR dengan menggunakan software $\mathrm{R}$ dan Octave. Berikut langkah-langkah yang dilakukan untuk menganalisis data dalam penelitian ini:

1. Melakukan analisis statistika deskriptif dan membuat peta deskriptif.

2. Mendeteksi multikolinearitas variabel bebas dengan kriteria VIF.

3. Membuat data terkoreksi (demean) dengan within estimator.

4. Pemodelan regresi panel global menggunakan software R.

5. Pemodelan GWPR menggunakan software Octave.

\section{HASIL DAN PEMBAHASAN}

\section{Deskriptif Data Variabel Terikat}

Deskripsi variabel terikat dapat dilihat melalui penyebaran persentase penduduk miskin di Provinsi Kalimantan Timur pada tahun 20172019 yang disajikan pada Gambar 4.1
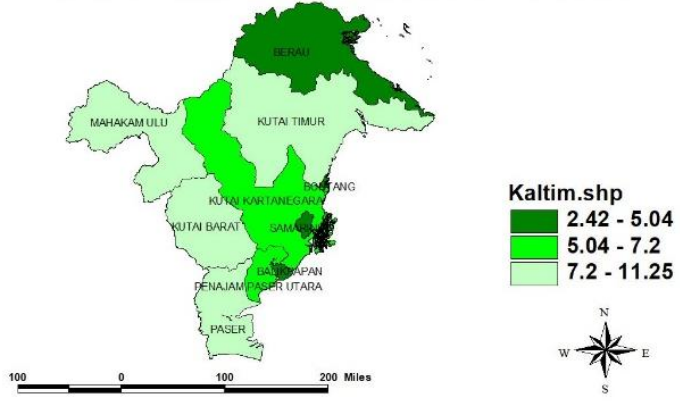

Gambar 4.1 Persentase Penduduk Miskin Tahun 2019

Berdasarkan Gambar 4.1 perkembangan persentase penduduk miskin semakin tahun mengalami perubahan. Hal ini, dapat dilihat pada perubahan warna pada wilayah Kabupaten Kutai Barat yang mengindikasikan terjadi perubahan persentase penduduk miskin di Kabupaten Kutai Barat

\section{Pendeteksian Multikolinearitas}

Multikolinearitas dapat dideteksi menggunakan kriteria nilai VIF. Nilai VIF dihitung berdasarkan persamaan (10). Hasil perhitungan disajikan pada Tabel 4.1.

Tabel 4.1 Nilai VIF Setiap Variabel Bebas

\begin{tabular}{cc}
\hline Variabel $\left(\boldsymbol{X}_{\boldsymbol{k}}\right)$ & $\mathbf{V I F}_{k}$ \\
\hline$X_{1}$ & 7,9520 \\
$X_{2}$ & 5,1837 \\
$X_{3}$ & 1,8092 \\
$X_{4}$ & 2,0740 \\
$X_{5}$ & 1,6953 \\
$X_{6}$ & 1,7211 \\
\hline
\end{tabular}

Berdasarkan nilai VIF pada Tabel 4.1 dapat disimpulkan bahwa tidak terdapat multikolinearitas antar variabel bebas. Hal ini ditunjukkan oleh nilai VIF setiap variabel kurang dari 10.

\section{Transformasi Data Aktual Menjadi Data Demean}

Transformasi data aktual menjadi data demean berdasarkan persamaan (3) sesuai dengan konsep within estimator.

\section{Pemodelan Regresi Panel}

Taksiran model regresi panel FEM diberikan pada persamaan (5), yaitu

$$
\begin{aligned}
& \hat{y}_{i t}^{*}=x_{i t 1}^{*} \hat{\beta}_{F_{1}}+x_{i t 2}^{*} \hat{\beta}_{F_{2}}+\ldots+x_{i t}^{*} \hat{\beta}_{F_{6}} ; \\
& i=1,2, \ldots, 10 ; t=1,2,3
\end{aligned}
$$

Penaksiran parameter menggunakan software $\mathrm{R}$ dan diperoleh hasil penaksiran yang disajikan pada Tabel 4.2

Tabel 4.2 Penaksiran Parameter FEM

\begin{tabular}{cc}
\hline Parameter $\left(\boldsymbol{\beta}_{F_{k}}\right)$ & Nilai Taksiran $\left(\hat{\boldsymbol{\beta}}_{F_{k}}\right)$ \\
\hline$\beta_{F_{1}}$ & 0,5874 \\
$\beta_{F_{2}}$ & $-2,6518$ \\
$\beta_{F_{3}}$ & $0,3403 \times 10^{-8}$ \\
$\beta_{F_{4}}$ & 0,0016 \\
$\beta_{F_{5}}$ & 0,0045 \\
$\beta_{F_{6}}$ & $-1,4425$ \\
\hline
\end{tabular}


Berdasarkan Tabel 4.2 maka taksiran model regresi panel FEM pada lokasi ke- $i$ dan waktu ke$t$ adalah :

$$
\begin{aligned}
\hat{y}_{i t}^{*}= & 0,5874 x_{i t 1}^{*}-2,6518 x_{i t 2}^{*}+0,3403 \times 10^{-7} x_{i t 3}^{*} \\
& +0,0016 x_{i t 4}^{*}+0,0045 x_{i t 5}^{*}-1,4425 x_{i t 6}^{*}
\end{aligned}
$$

Pengujian parameter secara simultan untuk mengetahui signifikansi parameter regresi terhadap variabel terikat secara simultan. Hipotesis pengujian parameter secara simultan adalah

$$
\mathrm{H}_{0}: \beta_{F_{1}}=\beta_{F_{2}}=\beta_{F_{3}}=\beta_{F_{4}}=\beta_{F_{5}}=\beta_{F_{6}}=0
$$

(Secara simultan, variabel bebas tidak berpengaruh terhadap persentase penduduk miskin Provinsi Kalimantan Timur)

$\mathrm{H}_{1}$ : minimal ada satu $\beta_{F_{k}} \neq 0, k=1,2, \ldots, 6$

(Secara simultan, variabel bebas berpengaruh terhadap persentase penduduk miskin Provinsi Kalimantan Timur)

Statistik uji yang digunakan adalah $\mathrm{F}_{1}$ yang diberikan oleh persamaan (8). Diperoleh nilai statistik uji $F_{1}$ dan pvalue yang disajikan pada Tabel 4.3.

Tabel 4.3 Pengujian Hipotesis Parameter Model Regresi Panel Secara Simultan

\begin{tabular}{cccc}
\hline $\boldsymbol{F}_{1}$ & $\boldsymbol{F}_{(0,05 ; ; ; 14)}$ & pvalue $_{1}$ & $\begin{array}{c}\text { Keputusan } \\
\mathbf{U j i}\end{array}$ \\
\hline 5,7473 & 2,8477 & 0,0034 & $H_{0}$ ditolak \\
\hline
\end{tabular}

Berdasarkan Tabel 4.3, diperoleh kesimpulan dari uji hipotesis menyatakan bahwa indeks pembangunan manusia, umur harapan hidup, pendapatan domestik regional bruto, tingkat partisipasi angkatan kerja, tingkat pengangguran terbuka, dan laju pertumbuhan penduduk secara simultan berpengaruh terhadap persentase penduduk miskin di Provinsi Kalimantan Timur. Hipotesis pengujian parameter secara parsial untuk parameter ke- $k(\mathrm{k}=1,2,3,4,5,6)$ adalah $\mathrm{H}_{0}: \beta_{F_{k}}=0$

(Variabel bebas $X_{k}$ tidak berpengaruh terhadap persentase penduduk miskin Provinsi Kalimantan Timur)

$\mathrm{H}_{1}: \beta_{F_{k}} \neq 0$

(Variabel bebas $X_{k}$ berpengaruh terhadap persentase penduduk miskin Provinsi Kalimantan Timur)

Statistik uji yang digunakan adalah $T_{1}$ yang diberikan oleh persamaan (9). Berdasarkan pengujian secara parsial yang disajikan pada Tabel 4.4.

Berdasarkan statistik uji $\mathrm{T}_{1}$ yang ditunjukkan pada Tabel 4.4, disimpulkan bahwa indeks pembangunan manusia, umur harapan hidup, dan laju pertumbuhan penduduk secara parsial berpengaruh terhadap persentase penduduk miskin. Hal ini ditunjukkan dari nilai statistik uji $\mathrm{T}_{1}$ ketiga variabel tersebut lebih dari 2,064 atau nilai pvalue ${ }_{2}$ masing-masing kurang dari 0,05. Pendapatan domestik regional bruto, tingkat partisipasi angkatan kerja, dan tingkat pengangguran terbuka secara parsial tidak berpengaruh terhadap persentase penduduk miskin.

\begin{tabular}{|c|c|c|c|}
\hline $\begin{array}{l}\text { Para- } \\
\text { meter }\end{array}$ & $\left|\boldsymbol{T}_{1}\right|$ & pvalue $_{2}$ & Keputusan Uji \\
\hline$\beta_{1}$ & 2,3200 & 0,0360 & $\mathrm{H}_{0}$ ditolak \\
\hline$\beta_{2}$ & 4,2565 & 0,0008 & $\mathrm{H}_{0}$ ditolak \\
\hline$\beta_{3}$ & 1,6051 & 0,1308 & $\begin{array}{c}\mathrm{H}_{0} \text { gagal } \\
\text { ditolak }\end{array}$ \\
\hline$\beta_{4}$ & 0,9245 & 0,3709 & $\begin{array}{c}\mathrm{H}_{0} \text { gagal } \\
\text { ditolak }\end{array}$ \\
\hline$\beta_{5}$ & 1,0421 & 0,3150 & $\begin{array}{c}\mathrm{H}_{0} \text { gagal } \\
\text { ditolak }\end{array}$ \\
\hline$\beta_{6}$ & 2,8914 & 0,0118 & $\mathrm{H}_{0}$ ditolak \\
\hline
\end{tabular}

Tabel 4.4 Pengujian Hipotesis Parameter Model Regresi Panel Secara Parsial

\section{Asumsi Model Regresi Panel}

Pada penelitian ini model regresi panel yang digunakan adalah model FEM, sehingga asumsi yang diuji hanya homoskedastisitas. Homoskedastisitas untuk mengetahui apakah galat memiliki variansi konstan menggunakan metode Glejser dengan hipotesis adalah $\mathrm{H}_{1}: \sigma_{1}^{2}=\sigma_{2}^{2}=\ldots=\sigma_{10}^{2}=\sigma^{2}$

(Variansi galat bersifat konstan di seluruh lokasi pengamatan)

$\mathrm{H}_{1}$ : minimal ada satu $\sigma_{i}^{2} \neq \sigma^{2} ; i=1,2, \ldots, 10$

(Variansi galat tidak konstan di seluruh lokasi pengamatan)

Statistik uji yang digunakan adalah statistik uji $F_{2}$ pada persamaan (11). Diperoleh nilai statistik uji dan pvalue yang disajikan pada Tabel 4.5 sebagai berikut: 
Tabel 4.5 Nilai Statistik Uji Pengujian Hipotesis Glejser Model Regresi Panel

\begin{tabular}{cccc}
\hline $\boldsymbol{F}_{2}$ & $\boldsymbol{F}_{(0,05 ; 6 ; 14)}$ & pvalue $_{3}$ & Keputusan Uji \\
\hline 4,0996 & 2,8477 & 0,0139 & $H_{0}$ ditolak \\
\hline
\end{tabular}

Berdasarkan Tabel 4.5 diperoleh kesimpulan yang berarti variansi galat tidak konstan di seluruh lokasi pengamatan. Pemodelan regresi panel diduga tidak sesuai sehingga dilakukan pemodelan Geographically Weighted Panel Regression (GWPR).

\section{Pemodelan Geographically Weighted Panel Regression}

Taksiran model GWPR pada lokasi ke- $i$ dan waktu ke- $t$ berdasarkan persamaan (19) adalah

$$
\begin{aligned}
\hat{y}_{i t}^{*}= & \hat{\beta}_{0}\left(u_{i}, v_{i}\right)+\hat{\beta}_{1}\left(u_{i}, v_{i}\right) x_{i t 1}^{*}+\hat{\beta}_{2}\left(u_{i}, v_{i}\right) x_{i t 2}^{*}+ \\
& \ldots+\hat{\beta}_{6}\left(u_{i}, v_{i}\right) x_{i t 6}^{*} ; i=1,2, \ldots, 10 ; t=1,2,3
\end{aligned}
$$

Langkah pertama dalam penaksiran parameter model GWPR adalah mencari matriks jarak euclidean antar titik lokasi pengamatan berdasarkan posisi geografis (longitude dan latitude). Langkah selanjutnya adalah menentukan bandwidth optimum di setiap lokasi pengamatan menggunakan kriteria $\mathrm{CV}$ berdasarkan persamaan (18). Proses untuk mendapatkan bandwidth yang meminimumkan CV dilakukan melalui metode Golden Section Search dan diperoleh nilai bandwidth yang optimum dan fungsi pembobot kernel yang terbaik adalah Adaptive Bisquare.

Berikut salah satu model GWPR Kabupaten Berau sebagai berikut:

$$
\begin{aligned}
\hat{y}_{2 t}^{*}= & -1,1278 \times 10^{-13}-0,2155 x_{2 t 1}^{*}-0,0769 x_{2 t 2}^{*}+ \\
& 6,0787 \times 10^{-8} x_{2 t 3}^{*}-0,0112 x_{2 t 4}^{*}-0,0185 x_{2 t 5}^{*}+ \\
& 0,0140 x_{2 t 6}^{*} ; t=1,2,3
\end{aligned}
$$

\section{Ukuran Kebaikan Model Regresi Panel dan Model Geographically Weighted Panel Regression}

Ukuran kebaikan yang digunakan adalah koefisien determinasi $\left(R^{2}\right)$ dan Root Mean Square Error (RMSE). Perbandingan nilai ukuran kebaikan disajikan pada Tabel 4.6 sebagai berikut:
Tabel 4.6 Ukuran Kebaikan Model Regresi Panel Global dan Model GWPR

\begin{tabular}{ccc}
\hline Model & $\boldsymbol{R}^{\mathbf{2}}(\boldsymbol{\%})$ & RMSE \\
\hline Model & 94,40 & 0,0451 \\
GWPR & 71,12 & 0,1025 \\
\hline
\end{tabular}

Berdasarkan Tabel 4.6 Model GWPR merupakan model yang lebih baik daripada model regresi panel dalam persentase penduduk miskin di Provinsi Kalimantan Timur. Model GWPR mampu menjelaskan keragaman persentase penduduk miskin sebesar 94,40\%. Nilai RMSE yang dihasilkan model GWPR lebih kecil daripada model global yaitu sebesar 0,0451.

\section{Pengujian Hipotesis Model Geographically Weighted Panel Regression}

Pengujian hipotesis yang dilakukan adalah pengujian model secara simultan sekaligus menguji kesesuaian (goodness of fit) dari model GWPR. Hipotesis pengujian adalah

$\mathrm{H}_{0}: \beta_{k}\left(u_{i}, v_{i}\right)=\beta_{k}$

(Tidak terdapat perbedaan yang signifikan antara model regresi panel dan GWPR)

$\mathrm{H}_{1}$ :minimal ada satu $\beta_{k}\left(u_{i}, v_{i}\right) \neq \beta_{k}$

(Terdapat perbedaan yang signifikan antara model regresi panel dan GWPR)

Statistik uji pengujian kesesuaian model adalah statistik uji $\mathrm{F}_{3}$ yang diberikan oleh persamaan (22). Hasil perhitungan statistik uji $\mathrm{F}_{3}$ dan pvalue ditunjukkan pada Tabel 4.7.

Tabel 4.7 Nilai Statistik Uji Pengujian Hipotesis Kesesuaian Model Secara Simultan

\begin{tabular}{cccc}
\hline $\boldsymbol{F}_{3}$ & $\boldsymbol{F}_{(0,05 ; 2 ; 15)}$ & pvalue $_{5}$ & $\begin{array}{c}\text { Keputusan } \\
\text { Uji }\end{array}$ \\
\hline 9,8202 & 2,2966 & $1,9246 \times 10^{-5}$ & $H_{0}$ ditolak \\
\hline
\end{tabular}

Berdasarkan Tabel 4.7 diperoleh kesimpul bahwa terdapat perbedaan yang signifikan antara model regresi panel dan GWPR.

Pengujian parameter secara parsial bertujuan untuk mengetahui pegaruh variabel bebas secara individu terhadap variabel terikat. Hipotesis uji parameter model adalah 
$\mathrm{H}_{0}: \beta_{k}\left(u_{i}, v_{i}\right)=0$

(Variabel bebas $X_{k}$ tidak berpengaruh terhadap persentase penduduk miskin di Provinsi Kalimantan Timur)

$\mathrm{H}_{1}: \beta_{k}\left(u_{i}, v_{i}\right) \neq 0$

(Variabel bebas $\mathrm{X}_{\mathrm{k}}$ berpengaruh terhadap persentase penduduk miskin di Provinsi Kalimantan Timur)

Statistik uji pengujian parameter secara parsial adalah statistik uji $\mathrm{T}_{2}$ yang diberikan oleh persamaan (23). Salah satu hasil pengujian parsial untuk Kabupaten Berau disajikan pada Tabel 4.8.

Tabel 4.8 Nilai Statistik Uji Pengujian Hipotesis Parameter Model GWPR Secara Parsial

\begin{tabular}{ccc}
\hline Parameter & $\boldsymbol{T}_{2}$ & pvalue $_{6}$ \\
\hline$\beta_{0}$ & $-7,9286 \times 10^{-12}$ & 1,0000 \\
$\beta_{1}$ & $-4,7762$ & $0,0003^{*}$ \\
$\beta_{2}$ & $-4,8403$ & $0,0002^{*}$ \\
$\beta_{3}$ & 5,3272 & $8,8836 \times 10^{-5} *$ \\
$\beta_{4}$ & $-1,5144$ & 0,1510 \\
$\beta_{5}$ & $-1,1208$ & 0,2802 \\
$\beta_{6}$ & 5,5769 & $5,5809 \times 10^{-5} *$ \\
\hline
\end{tabular}

Berdasarkan Tabel 4.8, faktor-faktor yang berpengaruh terhadap persentase penduduk miskin di Kabupaten Berau adalah indeks pembangunan manusia, umur harapan hidup, pendapatan domestik regional bruto, dan laju pertumbuhan penduduk.

Tabel 4.9 Kelompok Model GWPR Berdasarkan Faktor-Faktor yang Berpengaruh

\begin{tabular}{ccc}
\hline Kelompok & $\begin{array}{c}\text { Faktor yang } \\
\text { Berpengaruh }\end{array}$ & $\begin{array}{c}\text { Kabupaten } \\
\text { /Kota }\end{array}$ \\
\hline 1 & $\mathrm{X}_{3}$ & $\begin{array}{c}\text { Bontang } \\
\text { Kutai } \\
\text { Kartanegara }\end{array}$ \\
\hline 2 & $\mathrm{X}_{1}, \mathrm{X}_{2,} \mathrm{X}_{3}$, dan & $\begin{array}{c}\text { Berau } \\
\mathrm{X}_{6}\end{array}$ \\
Kutai Timur \\
\hline \multirow{2}{*}{3} & $\mathrm{X}_{1}, \mathrm{X}_{2}, \mathrm{X}_{4}$, dan \\
$\mathrm{X}_{6}$ & $\begin{array}{c}\text { Penajam Paser } \\
\text { Utara }\end{array}$ \\
\hline \multirow{2}{*}{4} & $\mathrm{X}_{1}, \mathrm{X}_{2}, \mathrm{X}_{3}, \mathrm{X}_{4}$, & $\begin{array}{c}\text { Paser } \\
\text { dan } \mathrm{X}_{6}\end{array}$ \\
& & Samarinda \\
\hline
\end{tabular}

\begin{tabular}{ccc}
\hline 5 & $\begin{array}{c}\mathrm{X}_{1}, \mathrm{X}_{2}, \mathrm{X}_{4}, \mathrm{X}_{5}, \\
\text { dan } \mathrm{X}_{6}\end{array}$ & Mahakam Ulu \\
\hline 6 & $\begin{array}{c}\mathrm{X}_{1}, \mathrm{X}_{2}, \mathrm{X}_{3}, \mathrm{X}_{4}, \\
\mathrm{X}_{5} \text { dan } \mathrm{X}_{6}\end{array}$ & Balikpapan \\
Kutai Barat
\end{tabular}

Berdasarkan Pengelompokkan model GWPR berdasarkan faktor-faktor yang berpengaruh pada Tabel 4.9 juga dapat dinyatakan dalam bentuk peta sebaran faktor-faktor yang mempengaruhi persentase penduduk miskin di Provinsi Kalimantan Timur seperti pada Gambar 4.2.

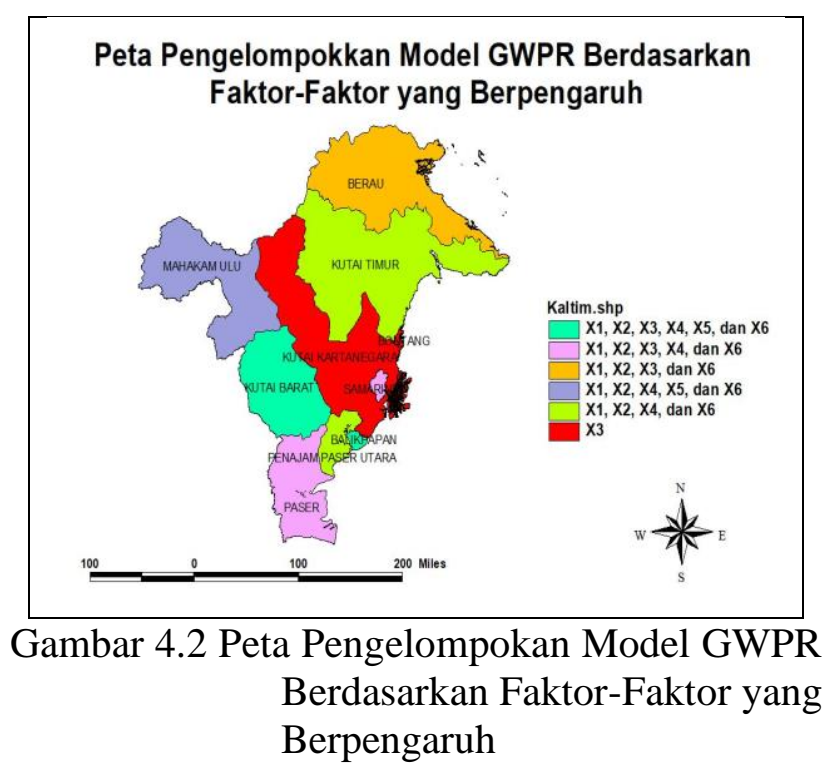

\section{Asumsi Model Geographically Weighted Panel Regression}

Pengujian asumsi homoskedastisitas menggunakan metode Glejser dengan hipotesis pengujian adalah

$\mathrm{H}_{0}: \sigma_{1}^{2}=\sigma_{2}^{2}=\ldots=\sigma_{10}^{2}=\sigma^{2}$

(Variansi galat bersifat konstan di seluruh lokasi pengamatan)

$\mathrm{H}_{1}$ : minimal ada satu $\sigma_{i}^{2} \neq \sigma^{2} ; i=1,2, \ldots, 10$

(Variansi galat tidak konstan di seluruh lokasi pengamatan)

Statistik uji yang digunakan adalah statistik uji $F_{2}$ yang diberikan pada persamaan (11). Diperoleh nilai statistik uji dan p-value yang disajikan pada Tabel 4.10.

Tabel 4.10 Nilai Statistik Uji Pada Pengujian Hipotesis Glejser Model GWPR

\begin{tabular}{cccc}
$\boldsymbol{F}_{2}$ & $\boldsymbol{F}_{(0,05 ; 6 ; 14)}$ & pvalue $_{3}$ & $\begin{array}{c}\text { Keputusan } \\
\text { Uji }\end{array}$ \\
\hline
\end{tabular}




\begin{tabular}{llll}
\hline 2,3298 & 2,8477 & 0,0902 & $\begin{array}{c}\mathrm{H}_{0} \text { gagal } \\
\text { ditolak }\end{array}$ \\
\hline
\end{tabular}

Berdasarkan Tabel 4.10 diperoleh kesimpulan yang berarti variansi galat konstan di seluruh lokasi pengamatan.

\section{KESIMPULAN}

Berdasarkan hasil dan pembahasan yang telah dilakukan, dapat ditarik beberapa kesimpulan yaitu

1. Hasil pengujian kesesuaian model menunjukkan bahwa model GWPR berbeda sinifikan terhadap model regresi panel, serta model yang dihasilkan berbeda antara satu dengan yang lainnya.

2. Kabupaten/kota di Kalimantan Timur mempunyai 6 kelompok berdasarkan variabel yang signifikan.

3. Pada model GWPR menghasilkan nilai $R^{2}$ sebesar $94,40 \%$ dan nilai RMSE sebesar 0,0451. Berikut ini adalah salah satu contoh model yang terbentuk menggunakan model GWPR untuk lokasi pengamatan

\section{DAFTAR PUSTAKA}

[1] Badan Pusat Statistik. (2020). Berita Resmi Statistik: Profil Kemiskinan di Indonesia Maret 2020

[2] Worldbank. (2009). Handbook on Poverty and Inequality. Washington DC: The World Bank

[3] Henninger, N., dan Snel, M. (2002). Where are the Poor? Experience with the Development and Use of Poverty Maps. Arendal: World Resources Institute and UNEP/GRID

[4] Qur'ani, A. Y. (2014). Pemodelan Geographically Weighted Regression Panel (GWR-Panel) Sebagai Pendekatan Model Geographically Weighted Regression (GWR) dengan Menggunakan Fixed Effect Model Time Trend. Jurnal Mahasiswa Statistik. 2(3)

[5] Hsiao, C. (2003). Analysis of Panel Data. New York: Cambridge University Press
[6] Badan Pusat Statistik Provinsi Kalimantan Timur. (2020). Berita Resmi Statistik: Profil Kemiskinan di Kalimantan Timur Maret 2020

[7] Greene. W. H. (2007). Econometrics Analysis 6th Edition. New Jersey: Prentice Hall

[8] Wooldridge, J. M. (2002). Econometric Analysis of Cross-section and Panel Data. London: MIT Press

[9] Meutuah, M. S., Yasin H., dan Maruddani D.A.I. (2017). Pemodelan Fixed Effect Geographically Weighted Panel Regression Untuk Indeks Pembangunan Manusia Di Jawa Tengah. Jurnal Gaussian. 6(2). 241250

[10] Prasanti, T. A. (2015). Aplikasi Regresi Data Panel untuk Pemodelan Tingkat Pengangguran Terbuka Kabupaten/Kota di Provinsi Jawa Tengah. Jurnal Gaussian, 4(3), 687-696

[11] Setiawan dan Kusrini. (2010). Ekonometrika. Yogyakarta: Penerbit ANDI

[12] Kutner, M.H., Nachtsheim, C.J., Neter, J., \& Li, W. (2005). Applied Linear Statistical Model 5th Edition. New York: McGraw-Hill

[13] Gujarati, D. N. (2003). Ekonometrika Dasar. Jakarta: Erlangga

[14]Pindyck, R.S. dan D.I. Rubinfeld. (1998). Econometric Models and Economic Forecast. $4^{\text {th }}$ Edition. McGraw-Hill Int'1 Edition

[15] Gujarati, D. N. (2004). Basic Econometrics Fourth Edition. New York: The McGrawHill Companies

[16]Widarjono. (2009). Ekonometrika Pengantar dan Aplikasinya, Edisi Ketiga. Yogyakarta: Ekonisia

[17] Yasin, H. (2011). Pemilihan Variabel pada Model Geographically Weighted Regression. Jurnal. Program Studi Statistika FMIPA UNDIP.

[18]Fotheringham, A.S., Brunsdon, C., dan Charlton, M. (2002). Geographically Weighted Regression : the Analysis of Spatially Varying Relationships. Chichester: Wiley 
11 - Arjun Pratama, Suyitno, dan Purnamasari

[19]Bruna, F., dan Yu, D. (2013). Geographically Weighted Panel Regression. XI Congreso Galego de Estatica $e$ Investigacion de Operations. A Coruna

[20]Wei, W.W.S. (2006). Time Series Analysis: Univariate and Multivariate Methods Second Edition. New Jersey: Pearson Prentice Hall.s 